\title{
KAJIAN REPRESENTASI INDONESIA PADA KARAKTER GATOTKACA DALAM GIM MOBILE LEGENDS MENGGUNAKAN METODE TRIANGULASI
}

\author{
Peter Rhian Gunawan, Berti Alia Bahaduri \\ (Email: peter.rhian.gunawan@gmail.com) \\ Desain Komunikasi Visual \\ Fakultas Seni Rupa dan Desain \\ Universitas Kristen Maranatha \\ Jl. Prof.drg. Suria Sumantri, MPH no. 65, Bandung, Indonesia
}

\begin{abstract}
ABSTRAK
Gatotkaca adalah salah satu pahlawan yang terkenal di dalam kultur pop Indonesia yang berasal dari karya sastra India Mahabharata. Di Indonesia, Gatotkaca banyak ditampilkan pada pertunjukkan wayang. Di masa modern, Gatotkaca banyak diadopsi ke dalam iklan, buku komik, karikatur dan terakhir ke dalam permainan online bernama Mobile Legends Bang Bang. Di Indonesia, Mobile Legends Bang Bang memiliki jumlah pemain terbesar bila dibandingkan dengan jumlah pemain dari belahan dunia lain. Dalam pengembangan gim-nya, Mobile Legends membuat karakter hero yang diambil dari Indonesia, yaitu Gatotkaca, ke dalam daftar hero mereka yang dapat dipilih oleh pemain. Pengembang permainan ini berharap agar karakter ini dapat merepresentasikan pemain dari Indonesia dan menambah daya tarik terhadap permainan ini. Asumsi awal dari penelitian ini adalah generasi pemain yang berusia 15- 30 tahun belum tentu mengenali ciri Indonesia dalam visualisasi karakter yang dikembangkan oleh Montoon, dimana perusahaan ini adalah perusahaan global yang bukan berasal dari Indonesia. Penelitian ini bertujuan untuk mengeksplorasi sejauh mana pemain muda Indonesia dapat mengenali karakter Gatotkaca dalam gim Mobile Legends dan untuk mengetahui mitos apa yang ingin dibangun oleh Montoon melalui karakter Gatotkaca, yang membuat pemain Indonesia tertarik untuk memainkannya. Peneliti menggunakan kuesioner dan focus group discussion dalam mengumpulkan informasi yang diperlukan. Hasil dari responden dianalisis menggunakan semiotika Barthes untuk memperoleh data yang menghubungkan antara persepsi pemain dengan ciri-ciri visual yang dimiliki oleh karakter hero dan digunakan metode triangulasi dari 3 sumber yaitu hasil FGD, survei dan teori penandaan Barthes, untuk melakukan perbandingan data. Representasi mitos yang ditemukan adalah karakter Gatotkaca sebagai karakter hero laki satu-satunya yang mewakili Indonesia yang memiliki kekuatan dewa, sangat maskulin dan tidak bersahabat, tetapi memiliki keagungan seorang raja. Para responden dapat mengindentifikasi Gatotkaca sebagai karakter dari Indonesia berdasarkan visual kostum, tetapi tidak semua aspek visual dari Gatotkaca merepresentasikan Indonesia. Selain itu terdapat kesalahan persepsi oleh generasi pemain 15-30 tahun terhadap identitas Indonesia. Keberadaan karakter Gatotkaca tidak mempengaruhi pemilihan karakter mereka ketika memainkan Mobile Legends.
\end{abstract}

Kata kunci: Gatotkaca; representasi Indonesia; semiotika

\section{ABSTRACT}

Gatotkaca is one of the famous heroes in Indonesian pop culture originating from the Mahabharata Indian literary work. In Indonesia, Gatotkaca is widely displayed in puppet shows. In modern times, Gatotkaca has been widely adopted into advertisements, comic books, caricatures, and recently into an online game called Mobile Legends Bang Bang. In Indonesia, Mobile Legends Bang Bang has the largest number of players compared to the number of players from other parts of the world. In the development of the game, Mobile Legends makes the hero was taken from Indonesia, Gatotkaca, into their list of heroes that can be chosen by players. The developer of this game hopes that this character can represent players from Indonesia and add to the appeal of this game. The initial assumption of this research is that the generation of players aged 15-30 years possibly does not recognize the Indonesian characteristics in the character 
visualization developed by Monsoon since this company is a global company that is not from Indonesia. This study aims to explore the extent to which young Indonesian players can recognize the Gatotkaca character in the Mobile Legends game and find out what myths Monsoon wants to build through the Gatotkaca character, which makes Indonesian players interested in playing it. Researchers use questionnaires and focus group discussions in gathering the necessary information. The results from the respondents and FGD then triangulated with Barthes's semiotics to compare data. The mythical representation found is that the character of Gatotkaca is the only male hero representing Indonesia who has the power of a god, very masculine and unfriendly, but has the majesty of a king. Respondents can identify Gatotkaca as characters from Indonesia based on visual costumes, but not all visual aspects of Gatotkaca represent Indonesia. In addition, there are misperceptions by generations of players from 15-30 years of the Indonesian identity. The existence of Gatotkaca characters does not affect their character selection when playing Mobile Legends.

Keywords: Gatotkaca; Indonesian representation; semiotics

\section{PENDAHULUAN}

Gim Mobile Legends: Bang Bang merupakan salah satu gim digital populer yang menggunakan platform gawai di Indonesia yang dikembangkan dan dirilis oleh Montoon, sebuah perusahaan gim yang berpusat di Malaysia. Mobile Legends tergolong gim dengan genre Multiplayer Online Battle Arena (MOBA) yang merupakan subgenre dari genre RTS (Real Time Strategy) di bawah kategori genre Strategi (Apperley, 2006). Mobile Legends yang dirilis di Indonesia pada tanggal 11 Juli 2016 memiliki jumlah pemain Indonesia terbanyak dibandingkan dengan negara lainnya di dunia, yaitu sebanyak 70 juta pemain di seluruh Indonesia. Gim Mobile Legends sendiri sudah menjadi fenomena baru dalam industri game dengan jumlah pemain sekitar 200 juta di seluruh dunia. Gim ini tersedia di 100 negara dengan dukungan 22 bahasa (Libriyanti, 2018)

Pada permainan dengan genre MOBA, pemilihan karakter hero menjadi salah satu mekanika permainan yang dapat menentukan pemain untuk meraih kemenangan dalam gim ini. Pada gim Mobile Legends: Bang Bang, terdapat sekitar 89 hero yang dapat dipilih oleh pemain dengan masing-masing hero memiliki kemampuan dan kekuatan yang berbeda-beda. Gatotkaca adalah salah satu hero dengan identitas karakter Indonesia yang dapat dipilih oleh pemain. Gatotkaca sendiri dirilis pada tanggal 21 Juli 2017 oleh Montoon dan bagi pemain yang telah memiliki battle poin minimal 32.000 sudah bisa memilih Gatotkaca sebagai hero, atau dengan diamond sebanyak 499 buah (Winarso, 2017) 


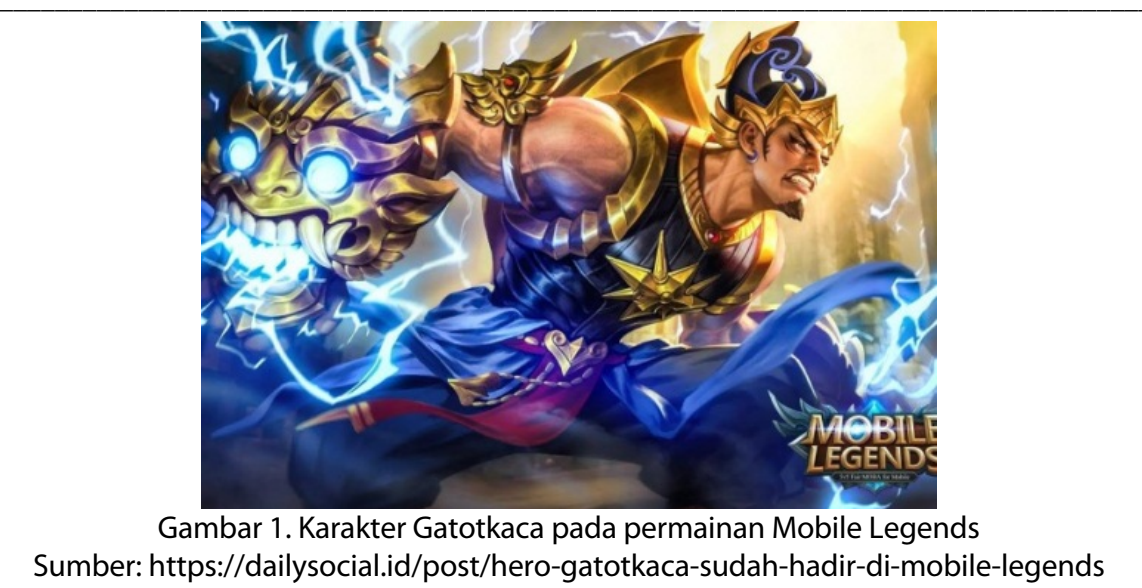

Pada tahun 2018, Moonton meluncurkan karakter pahlawan baru yaitu Gatotkaca. Menurut wawancara dengan Is Yuniarto melalui surel pada tanggal 9 Juni 2019, desainer Gatotkaca pada Mobile Legends, kehadiran hero ini dimaksudkan sebagai strategi pihak pengembang Montoon untuk menarik minat pemain Indonesia untuk memainkan gim Mobile Legends. Kehadiran Gatotkaca, memberikan makna representasi sosial bagi pemain terhadap gim Mobile Legends (Mallaby, 2007).

Objek kajian Gatotkaca dipilih karena karakter ini memiliki sejarah yang panjang di Indonesia. Gatotkaca pada cerita aslinya yang berasal dari India adalah seorang tokoh dalam kisah Mahabharata, putra Bimasena atau Wrekodara dari keluarga Pandawa dan ibunya adalah Hidimbi yang berasal dari keturunan raksasa. Gatotkaca dikisahkan memiliki kekuatan luar biasa. Dalam perang besar di Kurukshetra, ia menewaskan banyak sekutu Kurawa sebelum akhirnya gugur di tangan Karna.

Di Indonesia, Gatotkaca menjadi tokoh pewayangan yang sangat populer. Misalnya dalam pewayangan Jawa, ia dikenal dengan sebutan Gatotkoco (Bahasa Jawa: Gathotkaca). Kesaktiannya dikisahkan luar biasa, antara lain mampu terbang di angkasa tanpa menggunakan sayap, serta terkenal dengan julukan "otot kawat tulang besi". Karakter Gatotkaca sendiri mengalami transformasi secara visual ketika diceritakan kembali di pertunjukan-pertunjukan wayang ataupun ketika diadaptasi ke dalam buku komik. Salah satu serial komik yang mengangkat Gatotkaca adalah komik Mahabharata ciptaan R. A. Kosasih. Terakhir, Gatotkaca diadaptasi kembali oleh Montoon menjadi salah satu hero yang dapat dimainkan dalam gim mereka. 
Melalui penelitian ini, tim penulis bermaksud untuk menganalisis mitos yang terdapat pada karakter Gatotkaca ciptaan Montoon dan seberapa jauh pemain mengenali ciri visual identitas Indonesia di dalam karakter ini, berdasarkan elemen visual yang terdapat pada karakter bersangkutan dan menguji apakah dengan penyematan identitas Indonesia pada karakter Gatotkaca, pemain Indonesia akan lebih memilih memainkan karakter tersebut atau tidak. Serupa dengan penelitian Shiratuddin dan Zaibon (2010), ciri khas kelokalan (local content) dalam mobile game digunakan untuk menarik para pemain dari suatu daerah tertentu. Tampilan visual yang menunjukkan elemen kelokalan dan dapat diidentifikasikan oleh para pemain menjadi faktor penting dalam studi ini. Pemain dapat tertarik untuk memainkan dan mengerti unsur edukasi dari permainan LidiMan tersebut. Permainan ini ditujukan untuk anak usia 9-12 tahun. Penelitian ini mengungkapkan bahwa mereka dapat mengidentifikasi unsur kelokalan Malaysia dalam karakter-karakter LidiMan, dan membuat mereka terarik untuk memainkan LidiMan. Penelitian lainnya yang mengangkat identitas lokal dalam gim video adalah penelitian Penix-Tadsen (2019) yang mengemukakan bahwa tampilan karakter dan ruang sosial dapat menjadi teknik representatif untuk menampilkan identitas lokal dalam era globalisasi. Penelitian beliau adalah tampilan identitas Meksiko dalam gim-gim yang menampilkan Lucha Libre, liga gulat Meksiko. Tampilan identitas Meksiko membuat karakter-karakter dalam gim sebagai liyan/other yang familiar bagi para pemain, sehingga identitas Meksiko dapat tetap dilihat oleh para pemain. Para pemain berpartisipasi aktif melalui interaksi dengan karakter melalui gameplay dan dapat mengidentifikasi identitas visual Meksiko dari karakter dan suasana (setting).

Penelitian ini diharapkan dapat memberikan manfaat untuk pengembangan keilmuan dalam ruang lingkup desain komunikasi visual, khususnya game grafis yang dapat digunakan oleh game developer sebagai sumber data dalam pembuatan dan pengembangan karakter gim yang memiliki identitas kekhasan Indonesia.

\section{METODE PENELITIAN}

Peneliti menggunakan kuesioner dan focus group discussion dalam mengumpulkan 
informasi yang diperlukan. Hasil dari responden dianalisis menggunakan semiotika Barthes untuk memperoleh data yang menghubungkan antara persepsi pemain dengan ciri-ciri visual yang dimiliki oleh karakter hero dan digunakan metode triangulasi (Denzin,2000; Goetz \& LeCompte,1984). Metode triangulasi yang menggunakan 3 sumber data atau lebih digunakan untuk membandingkan hasil data dari masing2 metode sehingga tangkapan atas realitas sosial menjadi lebih terpercaya.

Sumber data berasal dari FGD, survei dan teori penandaan Barthes. Analisis semiotika terhadap objek karakter Gatotkaca yang memiliki identitas visual Indonesia. Dalam penelitian ini teknik pengumpulan data dilakukan secara bertahap. Tahap pertama adalah penyebaran kuesioner secara online. Sebuah link disertakan bagi pengisi survey yang akan mengarahkan mereka ke situs yang berisi serangkaian pertanyaan yang dapat mereka jawab secara sukarela. Responden penelitian dibatasi dari wilayah Kota Bandung sebagai kota besar yang penduduknya mayoritas telah memiliki gawai dan menggunakannya untuk bermain game online. Responden yang dituju merupakan purposive sampling, sehingga pada awal kuesioner sudah diberitahukan terlebih dahulu bahwa untuk mengisi kuesioner diutamakan oleh mereka yang telah memainkan Mobile Legends. Tanda (sign) dalam visual karakter Gatotkaca dipetakan dan disertakan untuk diuji persepsinya oleh responden yang mengisi kuesioner yang kemudian akan dianalisis menggunakan teori pertandaan Barthes dalam menjelaskan pemaknaan denotatif dan konotatif yang timbul. Aspek visual dari karakter Gatotkaca yang dipetakan adalah: (1) bentuk wajah, (2) bentuk tubuh, (3) pakaian dan (4) senjata. 


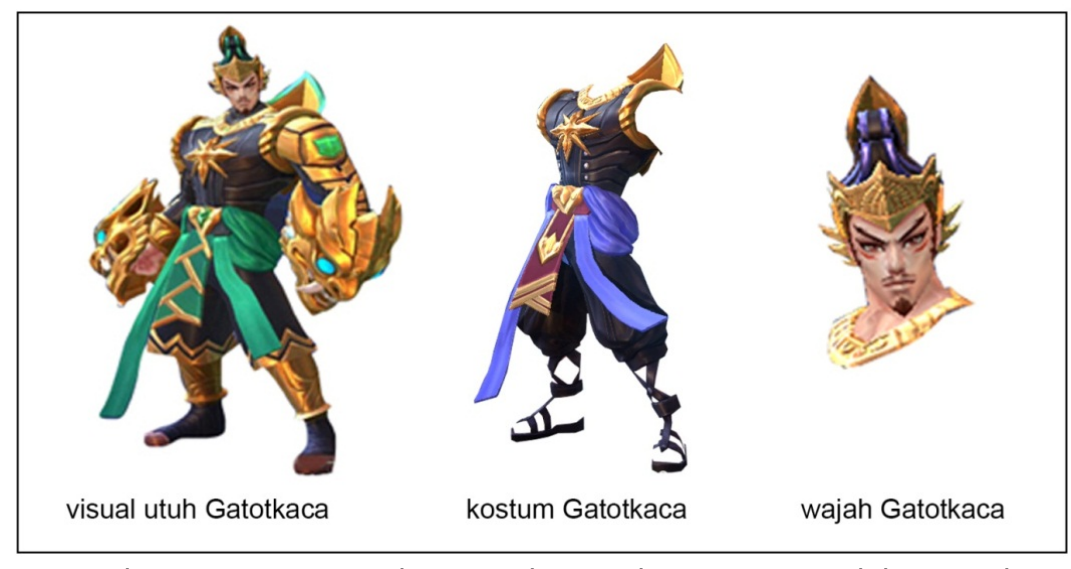

Gambar 2. Pemetaan Karakter Gatotkaca pada permainan Mobile Legends sumber: reka penulis

Teknik pengumpulan data lainnya adalah melalui diskusi kelompok (focus group discussion) yang melibatkan para pemain (player) gim berusia 17- 23 tahun yang berdomisili di Bandung. Selain itu, wawancara terhadap Is Yuniarto selaku desainer Gatotkaca pada Mobile Legends dilakukan untuk mengetahui latar belakang dalam proses penciptaan karakter tersebut.

\section{PEMBAHASAN}

Dalam Mobile Legends, pemain akan bekerjasama dalam satu regu yang mengutamakan strategi dalam usaha mengalahkan regu lainnya. Di dalam satu regu tersebut akan terdapat lima hero yang saling bekerjasama dalam satu putaran permainan. Setiap hero dalam Mobile Legends memiliki kekuatan dan keahlian yang berbeda-beda sehingga setiap hero harus saling melengkapi di dalam satu regu. Tercatat terdapat 89 hero yang dapat dipilih oleh pemain dalam permainan Mobile Legends. Masing-masing hero tersebut diklasifikasikan ke dalam enam kategori yaitu Assasin, Tank, Fighter, Mage, Marksman dan Support (sumber: mobilelegends.gcube.id). Dengan jumlah hero sebanyak itu, setiap pemain Mobile Legends akan mengidentifikasi karakter dan fungsinya masing-masing melalui desain masing-masing hero.

Ekspektasi pemain terhadap para hero ini berkaitan dengan presentasi/penampilan dan kesan secara visual, yang tentu saja ditentukan oleh tampilan fisik yang dimiliki karakter tersebut (Haake, Gulz, 2008). Teori ini menunjukkan bahwa presentasi visual 
dari karakter berperan sebagai ciri spesifik yang mewakili nilai-nilai, identitas, motivasi dan perwatakan yang dimilikinya. Asch (1946) mengatakan apabila kita melihat seseorang dan seketika itu juga kesan spesifik dari karakter tersebut membentuk dirinya di dalam pikiran kita, merupakan pencapaian karakter yang dicapai dengan jalan desain. Dari kedua teori di atas, dapat disimpulkan bahwa semua aspek visual yang terdapat pada karakter -bentuk badan, bentuk wajah, warna kulit, rambut, mata, hidung, pakaian, dan atribut yang dikenakanmemunculkan persepsi dan nilai-nilai bagi orang yang melihatnya, dalam hal ini pemain gim Mobile Legends.

Ekspektasi visual dari pemain dalam permainan real time strategy (RTS) menjadi salah satu aspek yang penting dalam setiap permainan yang memiliki waktu interaktif singkat. Dalam hal ini stereotip dapat membantu pemain untuk mengenali karakter yang akan mereka pilih, termasuk di dalamnya latar belakang karakter, fungsi, kekuatan, dan lain-lain. Courtney (1983) menyebutkan bahwa proses stereotip dapat menjadi jalan singkat untuk membantu menyampaikan ide-ide dan visual secara jelas dan cepat. Sebagai bagian dari semiotika, tim penulis menggunakan dua bentuk penanda, yaitu penanda situasi (situational signifiers) dan penanda penampilan (performance signifiers). Penanda situasional meliputi etnis, pekerjaan, orientasi, dan fitur lainnya yang berhubungan dengan narasi yang dimiliki oleh karakter, sedangkan penanda penampilan berhubungan dengan kemampuan, kekuatan dari karakter yang berhubungan dengan fungsi/ peran mereka di dalam game (Lee, 2013). Melalui analisis semiotika ini tim penulis akan mengkaji seberapa jauh pemain memahami karakter Gatotkaca, yang dapat dijadikan bahan pertimbangan pemilihan karakter tersebut untuk dimainkan.

\section{Analisis Persepsi Responden Kuesioner Online}

Tim penulis menentukan pertanyaan yang bermaksud untuk menggali persepsi responden dalam bentuk kuesioner online yang disebarkan kepada 104 responden, yang terdiri atas 69 laki-laki dan 35 perempuan dengan rentang umur 17-30 tahun. Pemetaan identitas visual pada Gatotkaca dimasukkan ke dalam kuesioner agar 
responden dapat mencirikan dan menjawab pertanyaan-pertanyaan dalam kuesioner tersebut. Berikut adalah hasil survey online yang berfokus pada persepsi mereka terhadap visual yang terdapat pada karakter Gatotkaca. Sebanyak 94,7\% responden mengetahui bahwa Gatotkaca berasal dari cerita rakyat tetapi hanya sebanyak 38,1\% responden yang mengetahui bahwa Gatotkaca berasal dari kisah Mahabharata. Sebanyak 48,7\% pemain pernah memilih Gatotkaca sebagai hero ketika memainkan Mobile Legends.

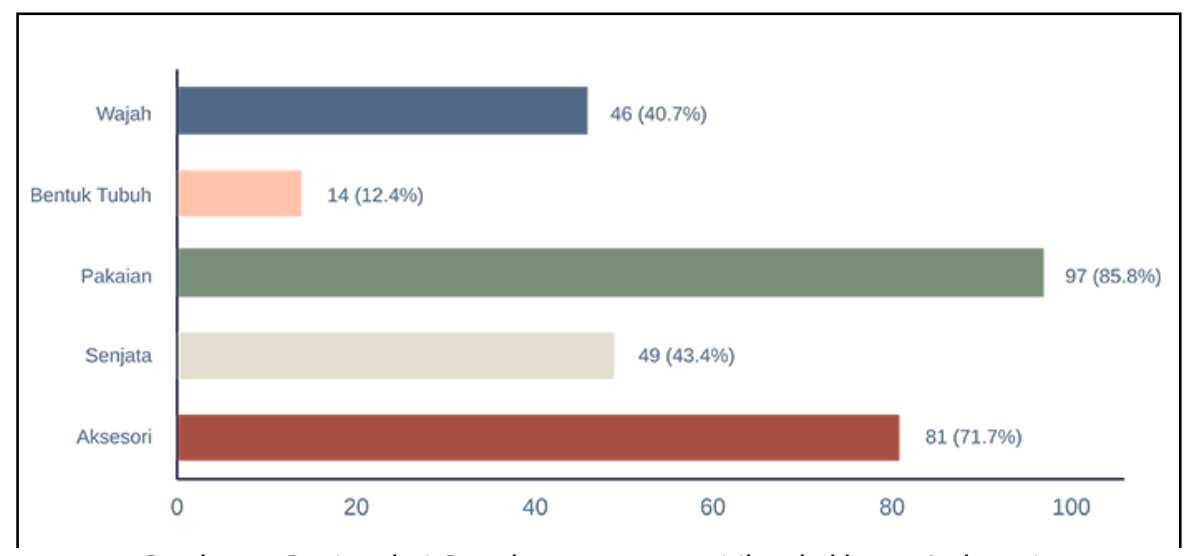

Gambar 3. Bagian dari Gatotkaca yang mencirikan kekhasan Indonesia sumber: dokumentasi penulis

Menurut responden, bagian dari karakter Gatotkaca yang paling menunjukkan kekhasan Indonesia adalah visual pakaian yang dikenakannya sebanyak $85,8 \%$, diikuti oleh aksesoris yang dikenakan sebanyak $71,7 \%$. Setelahnya adalah senjata dari Gatotkaca sebanyak 43,4\%, wajah 40,7\% dan bentuk tubuh 12,4\%. Responden pada bagian ini dapat memilih lebih dari satu pilihan.

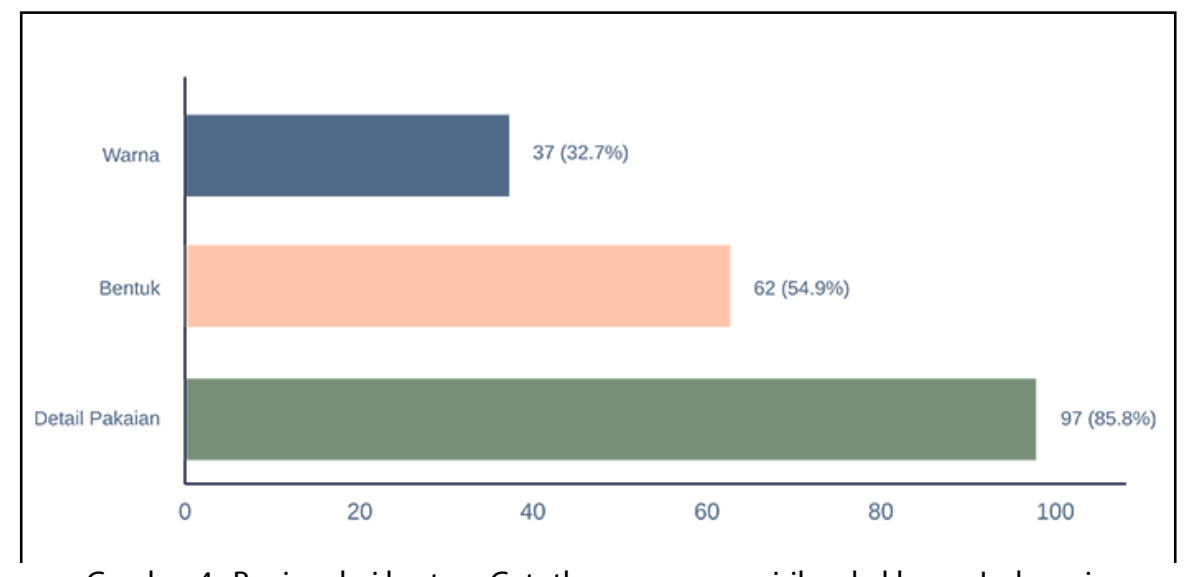

Gambar 4. Bagian dari kostum Gatotkaca yang mencirikan kekhasan Indonesia sumber: dokumentasi penulis 
Responden memilih detail dari pakaian yang menunjukkan representasi visual dengan kekhasan Indonesia sebesar 85,8\%, bentuk dari pakaian sebesar 54,9\%, sedangkan warna dari kostum sebesar $32,7 \%$.

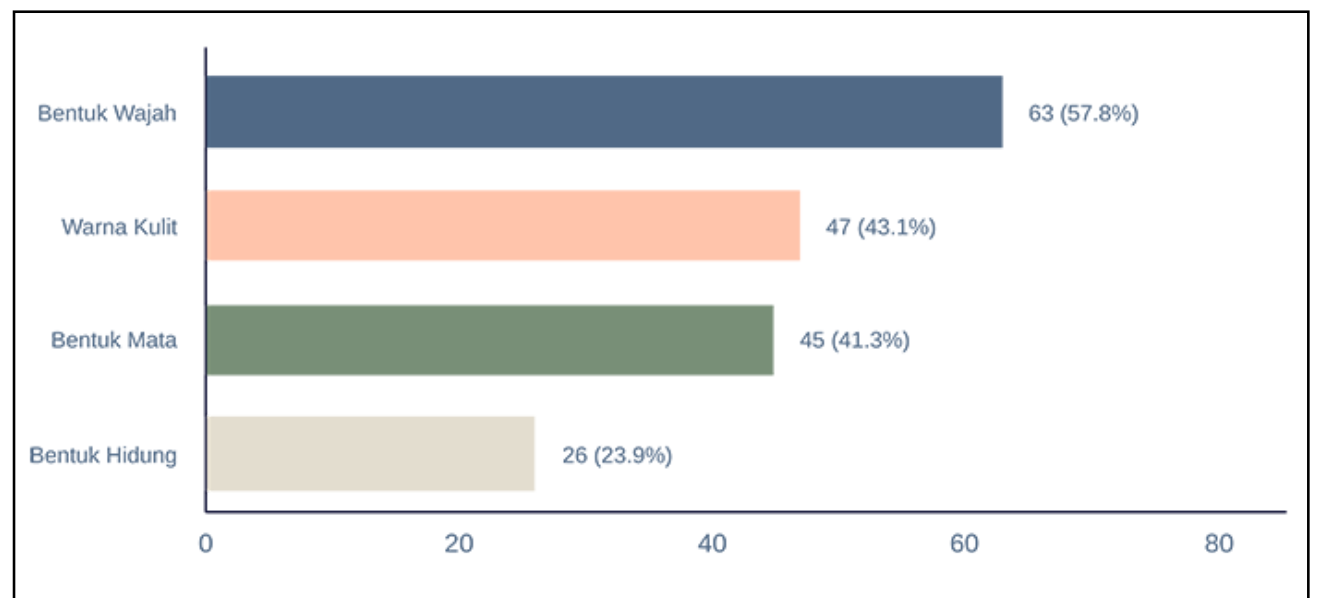

Gambar 5. Bagian dari wajah Gatotkaca yang mencirikan kekhasan Indonesia (sumber: dokumentasi penulis)

Responden memilih bentuk wajah sebagai bagian dari karakter Gatotkaca yang paling menunjukkan kekhasan Indonesia sebesar 57,8\%, warna kulit sebanyak 43,1\%, bentuk mata sebanyak 41,3\% dan bentuk hidung sebanyak 23,9\%. Responden pada bagian ini dapat memilih lebih dari satu pilihan.

\section{Analisis Persepsi Responden Focus Group Discussion}

Focus Group Discussion dilakukan pada tanggal 14 Mei 2019 dan dihadiri oleh 12 peserta yang semuanya pernah dan masih memainkan Mobile Legends dan terdiri atas 9 laki-laki dan 3 perempuan, berumur rata-rata 19-23 tahun. Semua peserta FGD mengetahui bahwa karakter Gatotkaca dalam Mobile Legends berasal dari Indonesia meskipun terdapat 4 peserta yang tidak mengetahui asal muasal cerita asli dan latar belakang karakter tersebut. Secara umum, peserta FGD yang pernah menggunakan hero Gatotkaca menyebutkan bahwa ability dari karakter tersebut yang menjadi pertimbangan mereka menggunakannya dan hanya satu peserta yang beralasan menggunakannya karena hero tersebut berasal dari Indonesia.

Melalui pertemuan FGD yang diadakan, penulis ingin mengetahui secara langsung persepsi dari responden terhadap tanda yang terdapat pada karakter Gatotkaca oleh 
Montoon. Hal ini untuk mengetahui seberapa dalam pemain gim Mobile Legends dapat mengidentifikasi ciri visual identitas Indonesia pada karakter tersebut.

Hasil pengumpulan data dari focus group discussion menunjukkan bahwa sebagian besar responden dapat mengidentifikasi ciri visual identitas Indonesia Gatotkaca dari beberapa elemen visual yang melekat pada karakter ini yaitu baju pusaka Gatotkaca, rompi sayap, dan gelang tangan yang digunakannya. Bagian baju lainnya seperti selendang dan celana juga mendukung representasi khas Indonesia pada karakter tersebut.

Berdasarkan diskusi yang dilakukan, terdapat beberapa perbedaan persepsi di antara responden mengenai visual fitur muka, tetapi mayoritas menyetujui bahwa warna kulit, kumis, dan jenggot menjadi penanda identitas Indonesia pada karakter ini. Beberapa pemain mengindentifikasikan visual wajah Gatotkaca berasal dari Suku Jawa atau Bali.

Dalam hal proporsi tubuh Gatotkaca, responden Focus Group Discussion berpendapat bahwa karakter Gatotkaca terlihat gagah dengan tampilan tubuh yang besar dan berotot. Gatotkaca pada permainan Mobile Legends diklasifikasikan ke dalam kategori Tank. Hero dalam kategori Tank pada umumnya memiliki proporsi badan yang kekar, tinggi, besar dan terlihat kokoh, sesuai dengan fungsinya yaitu dapat menerobos pertahanan lawan atau menahan lawan dengan kokoh. Elemen pembentuk siluet Gatotkaca menggunakan elemen kotak sebagai bentuk dasarnya. Bentuk kotak diasumsikan sebagai bentuk yang memiliki kestabilan, kekuatan dan percaya diri. Bentuk kotak dapat digambarkan sebagai pribadi yang besar dan mengancam atau sebagai pribadi yang menenangkan dan ceroboh. Bentuk ini seringkali digunakan untuk karakter superhero (Bancroft, 2006:35). 


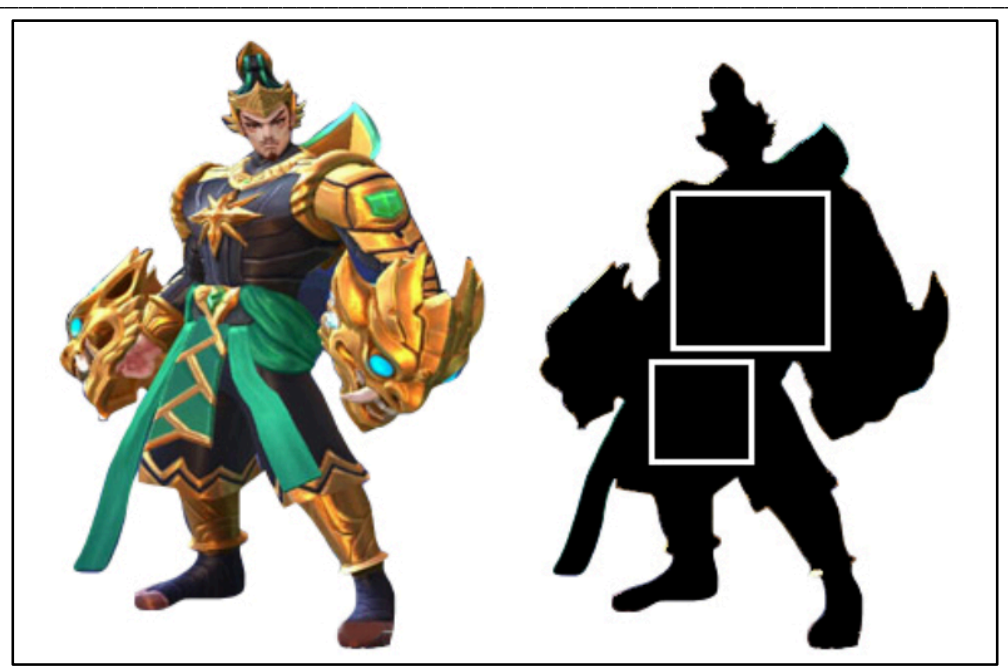

Gambar 6. Karakter Gatotkaca pada permainan Mobile Legends (ki) dan siluet Gatotkaca (ka) Sumber: https://dailysocial.id/post/hero-gatotkaca-sudah-hadir-di-mobile-legends dan reka penulis

\section{Wawancara dengan Is Yuniarto, Desainer Gatotkaca pada gim Mobile Legends}

Wawancara dengan Is Yuniarto dilakukan melalui korespondensi surel pada tanggal 9 Juni 2019. Is Yuniarto adalah desainer di balik karakter Gatotkaca yang dikembangkan oleh Montoon. la mengatakan bahwa pihak Montoon berinisiatif untuk mengangkat karakter Indonesia dalam rangka strategi pemasaran wilayah dengan mengangkat karakter yang akrab dengan para pemain dari Indonesia.

Pada awalnya Montoon melakukan dua tahapan survey: yang pertama adalah menentukan karakter Indonesia yang akan diangkat. Gatotkaca kemudian menjadi pilihan pertama responden diikuti oleh karakter Tuyul, Barong, Si Buta dari Goa Hantu, dan lain-lain. Setelah Gatotkaca terpilih, tahap kedua survey adalah menentukan bentuk Gatotkaca yang akan dikembangkan, dan hasilnya Gatotkaca versi ciptaan Is Yuniarto dalam Garudayana terpilih untuk dimasukkan ke dalam gim Mobile Legends.

Dalam tahap pengembangan karakternya, Is Yuniarto melakukan riset dengan mempelajari bentuk kostum detail dan watak berbagai wayang Gatotkaca di Indonesia (wayang kulit, wayang golek, dan wayang orang). Sumber utama riset lainnya adalah komik-komik klasik Mahabharata karya R. A. Kosasih, Ardisoma dan Teguh Santosa, yang terdapat perbedaan detail kostum dalam setiap komik tersebut, namun tetap memiliki beberapa ciri khas yang dapat digunakan. Pemilihan warna 
kostum dengan kombinasi hitam dan kuning merupakan warna identitas pada wayang Gatotkaca, sementara merah dan biru ditambahkan untuk identitas karakter superhero. Menurut Is, aspek penting yang menunjukkan identitas karakter yang berasal dari Indonesia, salah satunya adalah wujud Gatotkaca dengan logo bintang di dada yang hanya terdapat di Indonesia.

Dari segi riset dalam mengembangkan bentuk muka dari Gatotkaca, Is Yuniarto mengatakan bahwa ia tidak menggunakan manusia Indonesia sebagai referensi visualnya, melainkan hanya melanjutkan penggunaan karakter gaya gambar manga yang memang sudah menjadi ciri khas dari Yuniarto untuk fitur muka karakter ini dari versi sebelumnya, yaitu komik Garudayana. Begitupun dengan pemilihan warna kulit, Yuniarto hanya menggunakan warna kulit tersebut berdasarkan pemilihan gaya warna manga. Untuk fitur muka berupa kumis adalah salah satu ciri khas Gatotkaca versi Indonesia. Pada versi umum, kumisnya tebal seperti seseorang yang berusia 40-50 tahunan, sementara riset yang dilakukan Yuniarto menghasilkan kesimpulan bahwa Gatotkaca adalah pendekar muda (putra dari Bima), sehingga kumisnya didesain ulang lebih tipis untuk menampilkan usia yang lebih muda. Untuk proporsi tubuh Gatotkaca, Yuniarto menggunakan proporsi tubuh 1:8 sebagai proporsi tubuh ideal.

Untuk senjata berupa gauntlet yang bentuknya menyerupai kepala Kala, Yuniarto mengatakan bahwa hal tersebut sesuai dengan senjata Brajamusti milik Gatotkaca dalam komik Garudayana. Dalam gim tersebut, desain senjata disederhanakan dan disesuaikan dengan kebutuhan visual game.

\section{Analisis Semiotika pada Karakter Gatotkaca}

Tim penulis menganalisis semiotika yang terdapat pada visual karakter Gatotkaca menggunakan metode Barthes, yaitu Two Orders of Signification. Barthes di dalam John Fiske (2012) mendefinisikan yang pertama dari penandaan sebagai hubungan antara penanda dan yang ditandakan dalam tanda menuju realitas eksternal. Barthes menyebutnya sebagai denotasi, yaitu makna tanda yang paling jelas. Konotasi adalah istilah yang digunakan oleh Barthes untuk menunjukkan urutan penandaan kedua. Ini menggambarkan 
interaksi yang terjadi antara tanda dengan perasaan/ emosi pembaca atau nilai-nilai yang terdapat di kultur pembaca. Barthes mengemukakan bahwa mitos dalam pengertian khusus ini merupakan perkembangan konotasi. Konotasi yang sudah terbentuk lama di masyarakat disebut dengan mitos.

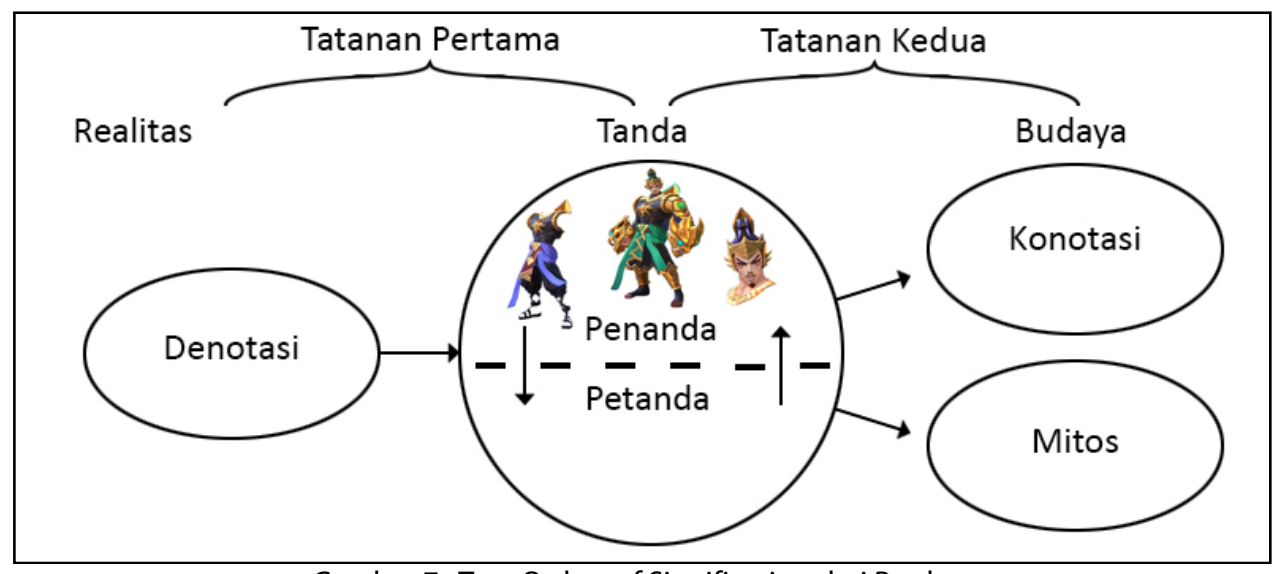

Gambar 7. Two Orders of Signification dari Barthes sumber: Fiske, 2012

Karakter Gatotkaca dalam gim Mobile Legends memiliki visualisasi dengan aspek semiotika yang cukup kompleks di dalam visualnya. Bentuk wajah Gatotkaca digambarkan memiliki bentuk rahang yang kokoh, hidung mancung, alis mata tebal dengan kumis tipis di atas mulut. Visualisasi matanya digambarkan mengernyit. Mata memiliki gaya visual manga dan kulit divisualisasikan memiliki warna kuning langsat. Bentuk wajah Gatotkaca yang menampilkan kesan maskulin dengan wajah tampan dengan hidung mancung, kumis tipis dan jenggot yang memiliki unsur mitos yang menambah gambaran Gatotkaca sebagai karakter yang sangat maskulin.

Bentuk tubuh Gatotkaca digambarkan berotot seperti tubuh binaragawan. Meskipun tidak terlalu tinggi, badan dari Gatotkaca memiliki proporsi badan yang kekar, besar dan kokoh. Secara simbol, Parrot dan Zeichner (2008) menandakan Gatotkaca sebagai seorang ksatria yang ditandakan dengan visual hipermaskulin yang berlebihan menunjukkan sifat permusuhan kepada kaum wanita dan pria. Secara pembahasan elemen game, pembentuk siluet Gatotkaca menggunakan elemen kotak sebagai bentuk dasarnya. Bentuk kotak diasumsikan sebagai bentuk yang memiliki kestabilan, kekuatan dan percaya diri. Bentuk kotak dapat 
digambarkan sebagai pribadi yang besar dan mengancam. Bentuk ini seringkali digunakan untuk karakter superhero (Bancroft, 2006:35).

Gatotkaca dalam visualisasi Mobile Legends, mengenakan pakaian dengan makna denotatif yang dapat dilihat memiliki visual kombinasi warna hitam dan biru, dengan lambang bintang besar berwarna emas menempel di dada. Gatotkaca mengenakan rompi sayap pada bagian punggung berwarna kuning, gelang tangan berwarna kuning dan selendang berwarna biru dan merah yang terikat pada bagian pinggang. Mahkota yang dikenakannya berwarna biru dan kuning. Makna konotatif dari warna hitam melambangkan kekuatan, maskulinitas, dan percaya diri. Sedangkan warna kuning keemasan pada lambang bintang, baju pusaka dan tutup kepala menunjukkan mitos mengenai kualitas keluhuran dan keagungan yang sesuai dengan sifat dan karakter dari Gatotkaca yang berbudi luhur. Menurut studi Fidelia (2018), Gatotkaca pada wayang kulit menggunakan warna merah, hijau, putih, hitam dan kuning sebagai kombinasi warna yang digunakan untuk kaum ksatria. Warna kuning yang mendominasi kostum Gatotkaca menunjukkan kemewahan dan menunjukkan sifat gagah.

Gatotkaca memiliki senjata berbentuk gauntlet dengan ukiran kepala singa barong berukuran besar bernama Brajamusti pada tangan kanannya dan Brajadenta pada tangan kirinya. Brajamusti dan Brajadenta merupakan roh kedua paman dari Gatotkaca yang telah meninggal dan masuk ke masing-masing tangan Gatotkaca. Di dalam versi kisah pewayangan, Gatotkaca tidak memiliki kedua gauntlet tersebut. Kedua gauntlet berwarna kuning keemasan tersebut memperlihatkan taringnya dan banyak memiliki sudut lancip pada bagian atas dan samping kepala. Kesan dari gauntlet Brajamusti dan Brajadenta yang dikenakan oleh Gatotkaca memperlihatkan suatu visual kekuatan yang seolah-olah dapat mengancam keselamatan lawannya. Bentuknya yang besar dan memiliki banyak sudut lancip memperlihatkan bahwa senjata tersebut sangat berbahaya bila digunakan. Warna kuning keemasan gauntlet tersebut memperlihatkan suatu kualitas keluhuran dan keagungan pada senjata 
yang menunjukkan bahwa kedua senjata tersebut bukanlah senjata sembarangan dan kemungkinan merupakan salah satu senjata yang dihormati keberadaannya.

\section{Analisis Data Menggunakan Metode Triangulasi Data}

Berdasarkan data yang penulis dapatkan dari hasil kuesioner, wawancara dan FGD, maka dapat ditemukan beberapa perbedaan persepsi di antara responden. Variabel yang penulis uji adalah bentuk wajah, bentuk tubuh, pakaian dan aksesoris yang tampak dalam karakter. Untuk membandingkan keseluruhan data yang didapat tim penulis, maka data akan dibandingkan dengan menggunakan metode triangulasi data. Triangulasi pada prinsipnya merupakan model pengecekan (crosscheck) data yang didapat untuk menentukan apakah data tersebut tepat dalam menggambarkan fenomena pada sebuah penelitian, pada umumnya dengan cara memanfaatkan sesuatu yang lain di luar data itu sendiri. Menurut Denzin (2000), triangulasi adalah langkah pemaduan berbagai sumber data, peneliti, teori, dan metode dalam suatu penelitian tentang suatu gejala sosial tertentu dengan memadukan sedikitnya tiga metode (Edukasi, 2015). Tim penulis menggunakan triangulasi dengan teknik pengumpulan data yang berbeda.

Berikut adalah tabel triangulasi data dari ketiga sumber beserta analisis semiotika:

Tabel 1. Triangulasi Data Penelitian

\begin{tabular}{|c|c|c|c|}
\hline $\begin{array}{c}\text { Hasil } \\
\text { wawancara } \\
\text { desainer } \\
\text { Gatotkaca }\end{array}$ & Denotasi & $\begin{array}{c}\text { Hasil Focus } \\
\text { Group } \\
\text { Discussion }\end{array}$ & Hasil Kuesioner \\
\hline \multicolumn{3}{|c|}{ Bentuk wajah } \\
\end{tabular}


Serat Rupa Journal of Design, July 2020, Vol.4, No.2: 111-134

E-ISSN: 2477-586X, ISSN: 2338-3348 | https://doi.org/10.28932/srjd.v4i2.2038 | Received: 19-11-2019, Accepted: 18-07-2020 Peter Rhian Gunawan, Berti Alia Bahaduri

Kajian Representasi Indonesia pada Karakter Gatotkaca dalam Gim Mobile Legends Menggunakan Metode Triangulasi

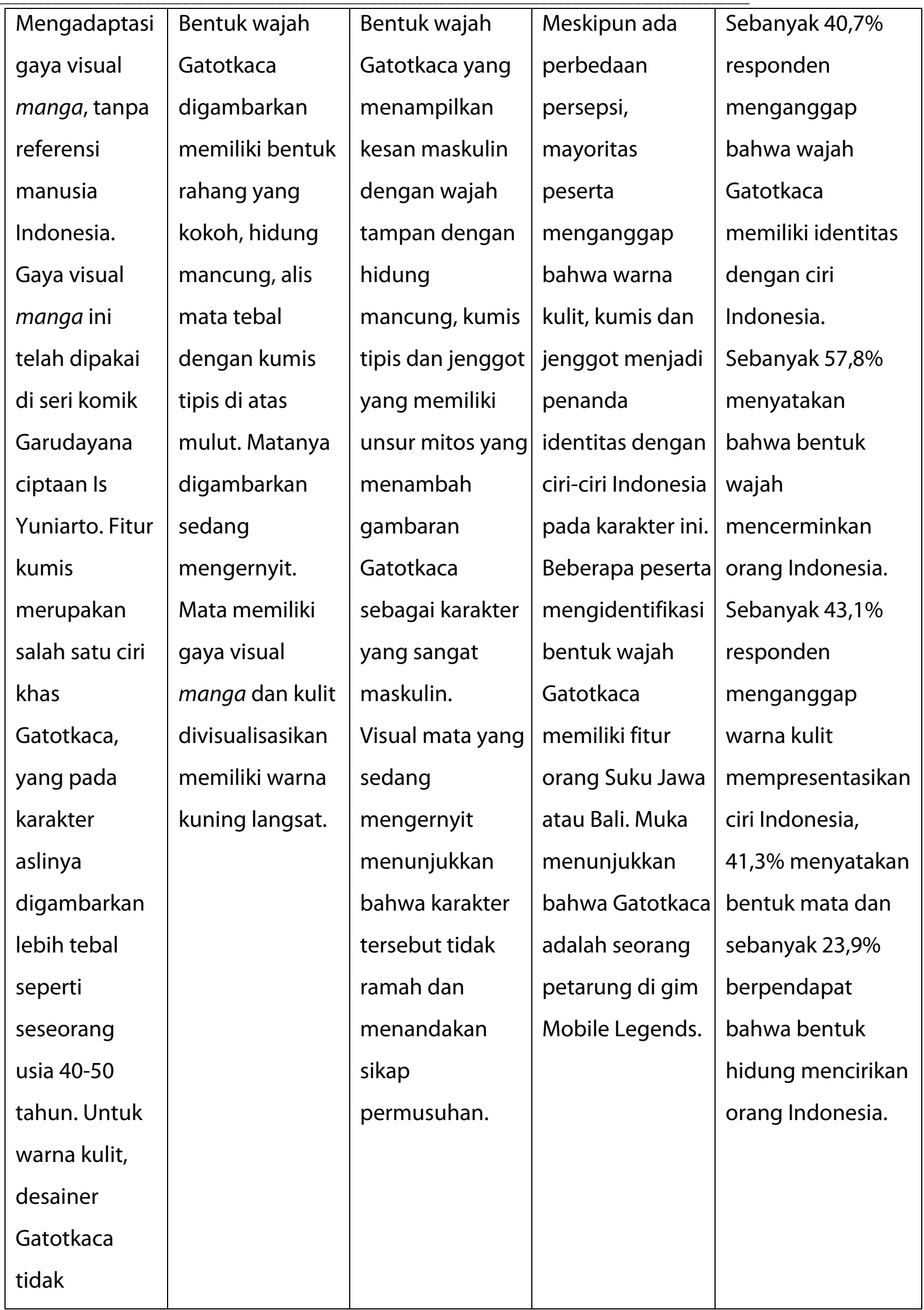




\begin{tabular}{|c|c|c|c|c|}
\hline $\begin{array}{l}\text { menggunakan } \\
\text { referensi } \\
\text { khusus. }\end{array}$ & & & & \\
\hline \multicolumn{5}{|c|}{ Bentuk tubuh } \\
\hline $\begin{array}{l}\text { Bentuk tubuh } \\
\text { Gatotkaca } \\
\text { didesain } \\
\text { menyesuaikan } \\
\text { fungsinya } \\
\text { sebagai Tank } \\
\text { di game } \\
\text { Mobile } \\
\text { Legends. } \\
\text { Fungsi Tank } \\
\text { berarti } \\
\text { karakter } \\
\text { tersebut } \\
\text { memiliki } \\
\text { kekuatan } \\
\text { spesifik untuk } \\
\text { menerobos } \\
\text { pertahanan }\end{array}$ & $\begin{array}{l}\text { Bentuk tubuh } \\
\text { Gatotkaca } \\
\text { digambarkan } \\
\text { berotot seperti } \\
\text { tubuh } \\
\text { binaragawan. } \\
\text { Meskipun tidak } \\
\text { terlalu tinggi, } \\
\text { badan dari } \\
\text { Gatotkaca } \\
\text { memiliki } \\
\text { proporsi badan } \\
\text { yang kekar, } \\
\text { besar dan } \\
\text { kokoh. }\end{array}$ & $\begin{array}{l}\text { Bentuk kotak } \\
\text { diasumsikan } \\
\text { sebagai bentuk } \\
\text { yang memiliki } \\
\text { kestabilan, } \\
\text { kekuatan dan } \\
\text { percaya diri. } \\
\text { Bentuk kotak } \\
\text { dapat } \\
\text { digambarkan } \\
\text { sebagai pribadi } \\
\text { yang besar dan } \\
\text { mengancam. }\end{array}$ & $\begin{array}{l}\text { Secara proporsi, } \\
\text { para peserta } \\
\text { Focus Group } \\
\text { Discussion } \\
\text { mengatakan } \\
\text { bahwa karakter } \\
\text { Gatotkaca } \\
\text { terlihat gagah } \\
\text { dengan } \\
\text { tampilan tubuh } \\
\text { yang besar } \\
\text { berotot, sesuai } \\
\text { dengan } \\
\text { fungsinya } \\
\text { sebagai hero } \\
\text { yang termasuk } \\
\text { ke dalam } \\
\text { klasifikasi Tank. }\end{array}$ & $\begin{array}{l}\text { Sebanyak 12,4\% } \\
\text { menyatakan } \\
\text { bahwa bentuk } \\
\text { tubuh karakter } \\
\text { Gatotkaca } \\
\text { mencirikan bentuk } \\
\text { tubuh orang } \\
\text { Indonesia. }\end{array}$ \\
\hline
\end{tabular}




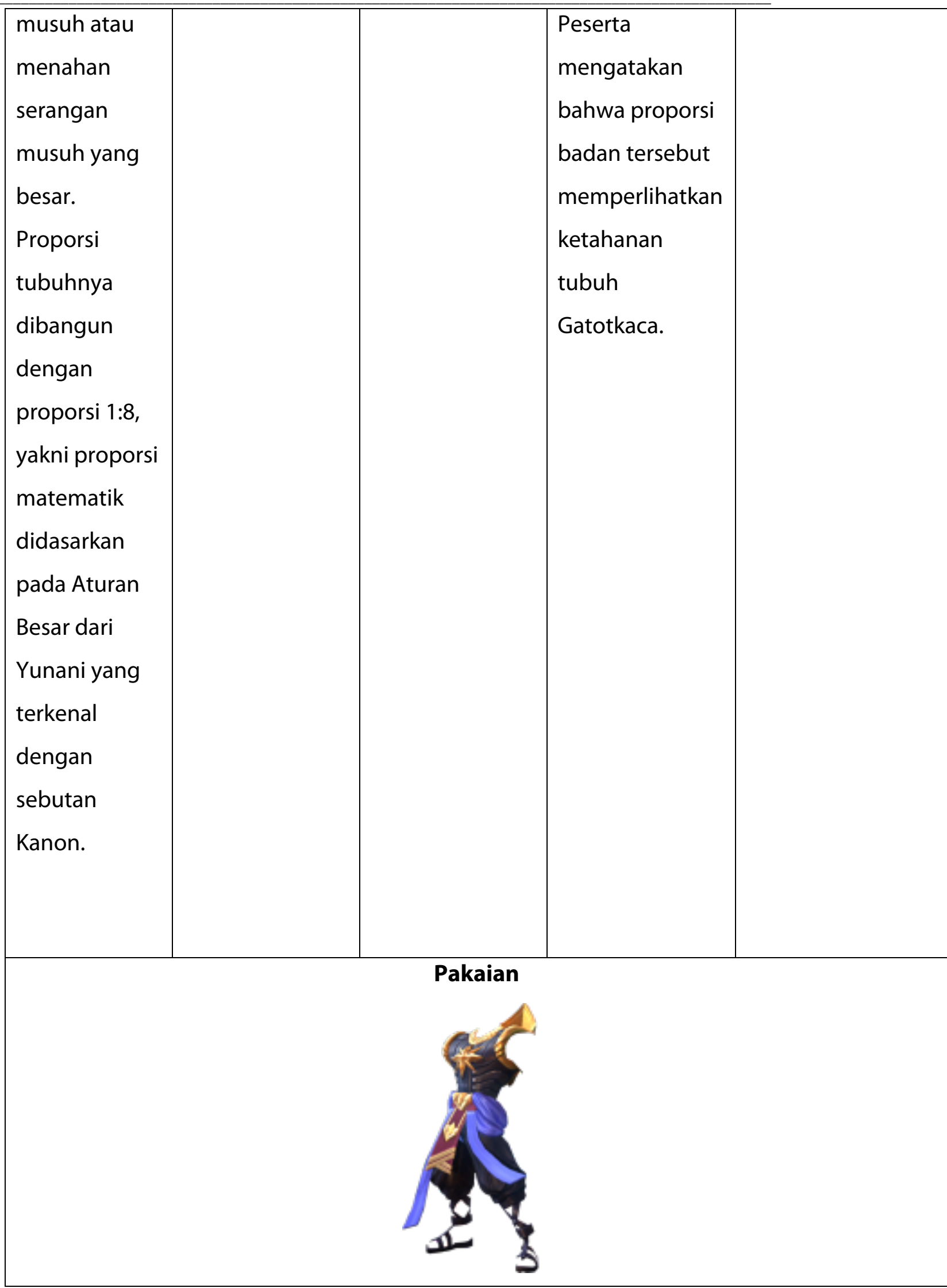


Serat Rupa Journal of Design, July 2020, Vol.4, No.2: 111-134

E-ISSN: 2477-586X, ISSN: 2338-3348 | https://doi.org/10.28932/srjd.v4i2.2038 | Received: 19-11-2019, Accepted: 18-07-2020 Peter Rhian Gunawan, Berti Alia Bahaduri

Kajian Representasi Indonesia pada Karakter Gatotkaca dalam Gim Mobile Legends Menggunakan Metode Triangulasi

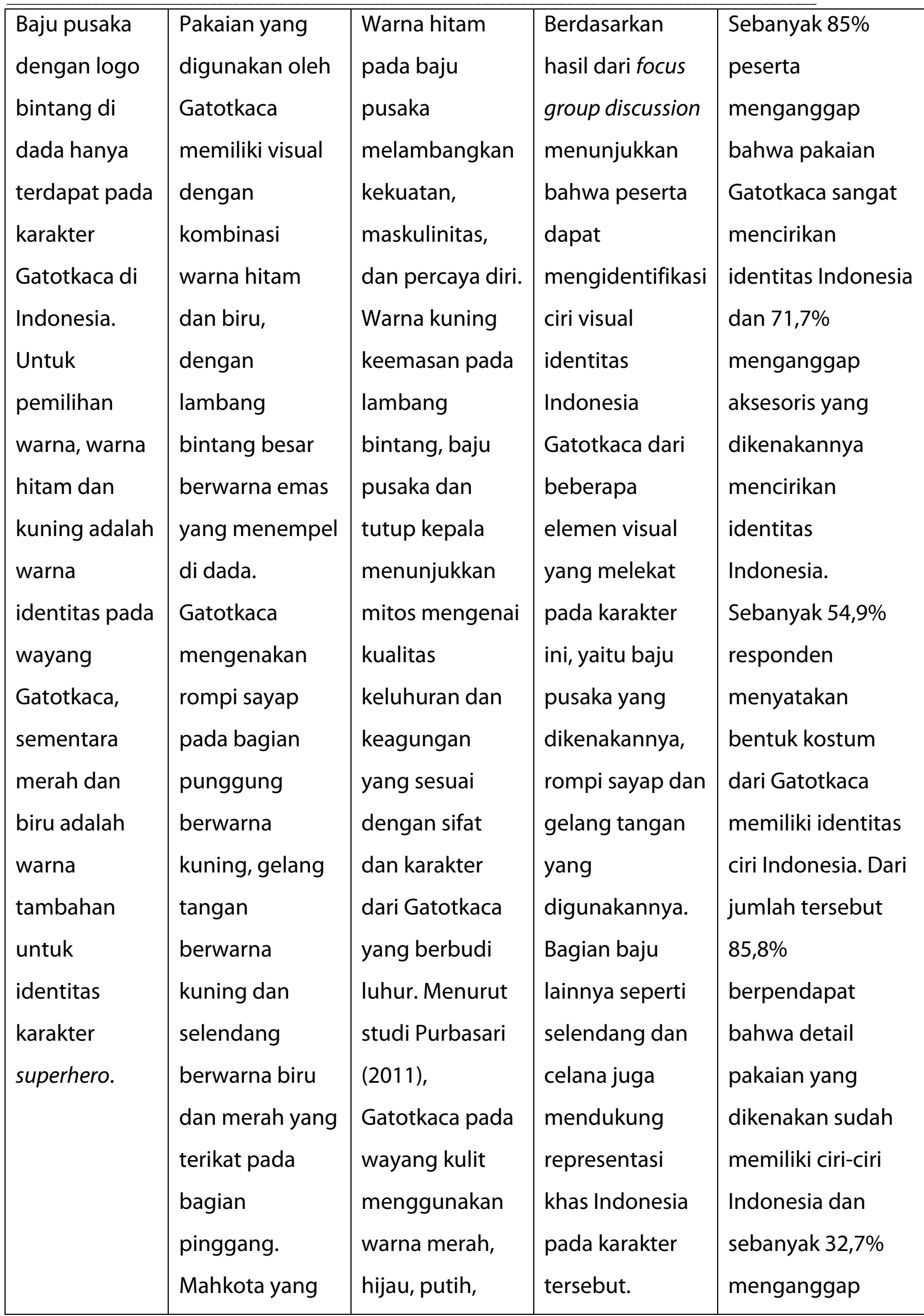


Serat Rupa Journal of Design, July 2020, Vol.4, No.2: 111-134

E-ISSN: 2477-586X, ISSN: 2338-3348 | https://doi.org/10.28932/srjd.v4i2.2038 | Received: 19-11-2019, Accepted: 18-07-2020 Peter Rhian Gunawan, Berti Alia Bahaduri

Kajian Representasi Indonesia pada Karakter Gatotkaca dalam Gim Mobile Legends Menggunakan Metode Triangulasi

\begin{tabular}{|c|c|c|c|c|}
\hline & $\begin{array}{l}\text { dikenakannya } \\
\text { berwarna biru } \\
\text { dan kuning. }\end{array}$ & $\begin{array}{l}\text { hitam dan } \\
\text { kuning sebagai } \\
\text { kombinasi } \\
\text { warna yang } \\
\text { digunakan } \\
\text { untuk kaum } \\
\text { ksatria. Warna } \\
\text { kuning yang } \\
\text { mendominasi } \\
\text { kostum } \\
\text { Gatotkaca } \\
\text { menunjukkan } \\
\text { kemewahan } \\
\text { dan } \\
\text { menunjukkan } \\
\text { sifat gagah. }\end{array}$ & & $\begin{array}{l}\text { warna dari baju } \\
\text { menunjukkan } \\
\text { kekhasan } \\
\text { Indonesia. }\end{array}$ \\
\hline \multicolumn{5}{|c|}{ Senjata } \\
\hline $\begin{array}{l}\text { Senjata } \\
\text { Brajamusti } \\
\text { dan } \\
\text { Brajadenta } \\
\text { diadaptasi } \\
\text { dari karakter } \\
\text { Gatotkaca }\end{array}$ & $\begin{array}{l}\text { Gatotkaca } \\
\text { memiliki senjata } \\
\text { berbentuk } \\
\text { gauntlet dengan } \\
\text { ukiran kepala } \\
\text { singa barong } \\
\text { berukuran besar }\end{array}$ & $\begin{array}{l}\text { Gauntlet } \\
\text { Brajamusti dan } \\
\text { Brajadenta yang } \\
\text { dikenakan oleh } \\
\text { Gatotkaca } \\
\text { memperlihatkan } \\
\text { suatu visual }\end{array}$ & $\begin{array}{l}\text { Peserta focus } \\
\text { group discussion } \\
\text { tidak } \\
\text { menganggap } \\
\text { bahwa senjata } \\
\text { Brajamusti dan } \\
\text { Brajadenta }\end{array}$ & $\begin{array}{l}\text { Sebanyak 43,4\% } \\
\text { responden } \\
\text { menyatakan } \\
\text { bahwa senjata } \\
\text { Gatotkaca } \\
\text { memiliki identitas }\end{array}$ \\
\hline
\end{tabular}


Serat Rupa Journal of Design, July 2020, Vol.4, No.2: 111-134

E-ISSN: 2477-586X, ISSN: 2338-3348 | https://doi.org/10.28932/srjd.v4i2.2038 | Received: 19-11-2019, Accepted: 18-07-2020 Peter Rhian Gunawan, Berti Alia Bahaduri

Kajian Representasi Indonesia pada Karakter Gatotkaca dalam Gim Mobile Legends Menggunakan Metode Triangulasi

\begin{tabular}{|c|c|c|c|c|}
\hline $\begin{array}{l}\text { versi komik } \\
\text { Garudayana. }\end{array}$ & $\begin{array}{l}\text { bernama } \\
\text { Brajamusti pada } \\
\text { tangan } \\
\text { kanannya dan } \\
\text { Brajadenta pada } \\
\text { tangan kirinya. } \\
\text { Kedua gauntlet } \\
\text { berwarna } \\
\text { kuning } \\
\text { keemasan } \\
\text { tersebut } \\
\text { memperlihatkan } \\
\text { taringnya dan } \\
\text { banyak memiliki } \\
\text { sudut lancip } \\
\text { pada bagian } \\
\text { atas dan } \\
\text { samping kepala. }\end{array}$ & $\begin{array}{l}\text { kekuatan yang } \\
\text { dapat } \\
\text { mengancam } \\
\text { keselamatan } \\
\text { lawannya. } \\
\text { Warna kuning } \\
\text { keemasan } \\
\text { gauntlet } \\
\text { tersebut } \\
\text { memperlihatkan } \\
\text { suatu kualitas } \\
\text { keluhuran dan } \\
\text { keagungan } \\
\text { pada senjata } \\
\text { yang } \\
\text { menunjukkan } \\
\text { bahwa kedua } \\
\text { senjata tersebut } \\
\text { bukanlah } \\
\text { senjata } \\
\text { sembarangan. }\end{array}$ & $\begin{array}{l}\text { merupakan } \\
\text { senjata yang } \\
\text { mewakili } \\
\text { kekhasan } \\
\text { identitas } \\
\text { Indonesia, tetapi } \\
\text { lebih mencirikan } \\
\text { visual senjata } \\
\text { yang berasal dari } \\
\text { Asia. }\end{array}$ & $\begin{array}{l}\text { kekhasan } \\
\text { Indonesia. }\end{array}$ \\
\hline
\end{tabular}

(Sumber: https://dailysocial.id/post/hero-gatotkaca-sudah-hadir-di-mobile-legends dan reka penulis)

\section{PENUTUP}

Berdasarkan hasil triangulasi data, maka tim penulis mendapatkan bahwa Gatotkaca sebagai tanda (sign) yang diproduksi oleh Montoon selaku perusahaan luar negeri memiliki tanda visual dengan identitas Indonesia, meskipun beberapa tanda di antaranya diproduksi dengan tidak dilatarbelakangi oleh riset yang mendalam. Berdasarkan analisis mitos, Gatotkaca pada gim video Montoon digambarkan sebagai karakter hero laki-laki satu-satunya mewakili Indonesia yang memiliki kekuatan dewa, sangat maskulin dan tidak bersahabat, dan memiliki keagungan seorang raja yang memiliki nilai-nilai berbudi luhur. Senjata yang dimilikinya 
Serat Rupa Journal of Design, July 2020, Vol.4, No.2: 111-134

E-ISSN: 2477-586X, ISSN: 2338-3348 | https://doi.org/10.28932/srjd.v4i2.2038 | Received: 19-11-2019, Accepted: 18-07-2020 Peter Rhian Gunawan, Berti Alia Bahaduri

Kajian Representasi Indonesia pada Karakter Gatotkaca dalam Gim Mobile Legends Menggunakan Metode Triangulasi

memiliki kekuatan yang dapat mengancam keselamatan musuh dan memperlihatkan suatu kualitas keluhuran dan keagungan.

Berdasarkan hasil kuesioner, responden setuju bahwa karakter Gatotkaca tersebut merepresentasikan karakter dari Indonesia meskipun dengan adanya variasi penerimaan yang beragam. Penerimaan identitas Indonesia pada elemen fesyen dan atribut yang dikenakan Gatotkaca berada di atas 50\%, terutama pada elemen fesyen di atas $80 \%$. Hal ini cukup berbanding terbalik dengan penerimaan fitur muka, bentuk tubuh dan senjata yang berada di bawah $50 \%$ dari jumlah responden.

Pengidentifikasian fitur muka Gatotkaca sebagai representasi suku asal Jawa atau Bali menjadi hal yang menarik, mengingat pada sumber data berdasarkan wawancara dengan desainer penggagas, mengatakan bahwa ia menggunakan gaya manga untuk penggambaran fitur muka. Hal ini membuktikan bahwa adanya interpretasi tanda yang bergeser pada generasi usia tersebut mengenai fitur muka Indonesia. Mengapa hal ini dapat terjadi, tentu saja memerlukan penelitian lebih lanjut untuk pendalaman yang lebih spesifik.

Dengan diterimanya karakter Gatotkaca sebagai karakter yang mempresentasikan Indonesia, apakah membuat pemain gim Indonesia lebih memilih menggunakan karakter tersebut di dalam gim Mobile Legends? Hal tersebut ternyata tidak terbukti dari jawaban responden. Berbeda dengan gim LidiMan, usia target pemain Mobile Legends yang berkisar antara 17-30 tahun memiliki pilihan permainan mobile yang lebih luas. Alasan responden kuesioner dan FGD untuk memilih karakter bukanlah berdasarkan bentuk karakter yang familiar, melainkan dari fungsi karakter dalam tim. Fungsi setiap karakter diterjemahkan oleh pemain dari bentuk wajah, tubuh, kostum dan senjata yang tampak dalam visualisasi karakter.

Pada akhirnya, data menunjukkan bahwa Montoon sebagai pengembang karakter Gatotkaca cukup berhasil menempatkan karakter ini sebagai hero yang merepresentasikan Indonesia. Hal ini ditunjukkan dengan penerimaan responden 
Serat Rupa Journal of Design, July 2020, Vol.4, No.2: 111-134

E-ISSN: 2477-586X, ISSN: 2338-3348 | https://doi.org/10.28932/srjd.v4i2.2038 | Received: 19-11-2019, Accepted: 18-07-2020 Peter Rhian Gunawan, Berti Alia Bahaduri

Kajian Representasi Indonesia pada Karakter Gatotkaca dalam Gim Mobile Legends Menggunakan Metode Triangulasi

yang cukup baik terhadap unsur mitos dari karakter ini meski terdapat fakta yang memperlihatkan adanya ketidakcocokan visual identitas Indonesia pada karakter setelah triangulasi data. Hal ini menguatkan pernyataan dari Penix-Taden (2019) yang menyatakan gim video mereproduksi dan mempresentasikan objek yang bisa saja memiliki nilai budaya berbeda dari yang diwakilinya dalam gim video. Pemain gim tidak diberikan ruang untuk tidak menyetujui nilai budaya yang terkandung dalam objek yang diproduksi gim video tersebut. Pemain hanya berinteraksi secara terbatas sesuai dengan peran yang diberikan terhadap objek tersebut. Dengan demikian, pemain seakan menerima karakter Gatotkaca yang dikembangkan oleh Montoon sebagai karakter yang merepresentasikan Indonesia, meskipun pada kenyataannya karakter tersebut tidak sepenuhnya mewakili identitas Indonesia.

\section{DAFTAR PUSTAKA}

Acuan dari buku dan jurnal:

Apperley, Thomas H. (2006). Genre and Game Studies: Toward a Critical Approach to Video Game Genres. Sage Publications.

Asch, S. E. (1946). Forming impressions of personality. The Journal of Abnormal and Social Psychology, 41(3), 258-290. https://doi.org/10.1037/h0055756.

Bancroft, Tom. (2006). Creating Characters with Personality. New York: Random. House Inc. Courtney, Alice E., Thomas W. Whipple. Sex Stereotyping in Advertising. Lexington, MA: Lexington, 1983.205. Print.

Denzin, Norman K. Lincoln, YS. (2000). Handbook of Qualitative Research. London: Sage Publications.

Fidelia, Rafika; Pratama, Dendi. (2018). Busana Kerajaan Tokoh Gatotkaca Wayang Kulit Purwa Gaya Surakarta. Visual Heritage; Jurnal Kreasi Seni dan Budaya.

Fiske, John. (2012). Pengantar Ilmu Komunikasi. Jakarta: PT. Rajagrafindo Persada.

Haake, M. \& Gulz, A. (2008). Visual Stereotypes and Virtual Pedagogical Agents. Journal of Educational Technology \& Society, 11(4), 1-15.

Malaby, Thomas M. (2007). Game and Play: A New Approach to Games. Games and Culture. October 18, 2007. http://sagepub.com.

Parrott, D. and Zeichner, A. (2008). Determinants of anger and physical aggression based on sexual orientation: An experimental examination of hypermasculinity and 
Serat Rupa Journal of Design, July 2020, Vol.4, No.2: 111-134

E-ISSN: 2477-586X, ISSN: 2338-3348 | https://doi.org/10.28932/srjd.v4i2.2038 | Received: 19-11-2019, Accepted: 18-07-2020 Peter Rhian Gunawan, Berti Alia Bahaduri

Kajian Representasi Indonesia pada Karakter Gatotkaca dalam Gim Mobile Legends Menggunakan Metode Triangulasi

exposure to male gender role violations. Archives of Sexual Behavior, 37(6): 891901.

Penix-Tadsen, Phillip. (2019). Video Games and the Global South. Carnegie Mellon University.Book. https://doi.org/10.1184/R1/8148680.v1.

Shiratuddin, Norshuhada. Zaibon, Syamsul Bahrun. (2010). Mobile game-based Learning with Local Content and Appealing Characters. International Journal Mobile Learning and Organisation, Vol. 4, No. 1.

\section{Acuan dari Tesis:}

Lee, Christopher S. (2013). Broad Semiotics in Character Design. The Savannah College of Art and Design.

Purbasari, Tyas. (2011). Kajian Aspek Teknis Estetis dan Simbolis Wanra Wayang Kulit Karya Perajin Wayang Desa Tunahan Kabupaten Jepara. Jurusan Seni Rupa Fakultas Bahasa dan Seni Universitas Negeri Semarang, Skripsi.

Acuan dari berita online:

Winarso, Bambang. (2017). Hero GatotKaca Sudah Hadir di Mobile Legends, Apa Hebatnya?. https://dailysocial.id/post/hero-gatotkaca-sudah-hadir-di-mobile-legends, diakses pada tanggal 13 November 2019

Libriyanti, Andina. (2018). Indonesia Penyumbang Pengguna Aktif Terbesar untuk Mobile Legends. https://www.liputan6.com/tekno/read/3637149/indonesia-penyumbangpengguna-aktif-terbesar-untuk-mobile-legends, diakses pada tanggal 11 November 2019.

Edukasi. (2015). Penelitian Kualitatif: Empat Tipe Triangulasi Pengumpulan Data. https://www.kompasiana.com/mtf3lix5tr/5535a2946ea8347510da42d9/penelitian kualitatif-024-empat-tipe-triangulasi-dalam-pengumpulan-data, diakses pada tanggal 24 Mei 2020. 